\title{
Intersectoral Linkage by Computable General Equilibrium Approach
}

\author{
P. Sangeetha ${ }^{1 *}$ and M. Chinnadurai ${ }^{2}$ \\ ${ }^{1}$ Department of Agricultural Economics, Centre for Agriculture and Rural Development \\ Studies (CARDS), Tamil Nadu Agricultural University (TNAU), Coimbatore-03, India \\ ${ }^{2}$ Centre for Agriculture and Rural Development Studies, Tamil Nadu Agricultural University, \\ Coimbatore-03, India \\ *Corresponding author
}

\section{A B S T R A C T}

\section{Key words}

Sectoral linkages, Social Accounting Matrix (SAM), Equilibrium (CGE) approach

\section{Article Info}

Accepted:

07 November 2018

Available Online:

10 December 2018
The present study deals with the review study of CGE model. The CGE model as general algebraic framework was developed from micro level economic fundamentals and used in the calibration of model through economic data in Social Accounting Matrix (SAM), to solve the equilibrium value of economic variables by forming numerical equations and for suggesting the policy framework by simulating major economic variables and observing its impact on the entire economic system.

\section{Introduction}

Interdependence among the sectors is one of the most needed phenomena for survival. The region is said to be economically developed when the weaker section of the region develops. The weaker section always remains in the rural region whose only dependence is farming and labour. For a developing economy there should be vast agricultural performance and industrial growth. In many ways both agriculture and industry are interdependent and influence each other. Agriculture generates demand for industrial products while farming like polyhouse construction, precision farming, machinery, fertilizer, tools, engineering works and etc.

The agriculture based industrial sectors are very need fully dependent on agriculture from head to toe. It requires each and every part of the crop / tree as raw materials to produce its 
own output/ final product. The households who own the factors of production to firms and farming are the final consumers of produced commodities (like clothing, footwear, sugar, edible oils, furniture and other value additions) and firms rent the factor of production from household for producing goods and services that households, farmers and Rest of World (ROW) then consume. ROW (which is called outside the study region), also supplies raw materials and other factors as demanded by firms/ farmers for their production process.

\section{Nature of sectoral linkages}

Since backbone of India is agriculture, the interrelationship between agriculture and agro based industry had received major attention among the researchers and policy makers. In India, the past study related to sectoral linkages highly followed Lewisian 'twosector' framework. The industry sector had a close relationship with agriculture due to the agro-based industrial structure in the preindependence and early post-independence period.

The sectors with strongest linkage tend to stimulate rapid growth in production, income, employment and plays very crucial role in poverty alleviation (Hirschman, 1958). From Hirschman's theory of 'Unbalanced growth', the sectoral linkage had been initially evolved and it was an important contribution and guide for economic development.

During mid 1960s, industrial sector showed slow growth and stagnation which severely attributed the stunned agricultural growth and favorable agricultural trade (Patnaik, 1972; Nayyar, 1978; Bathla, 2003). During 1980s and 1990s interdependence between the two sectors had found to be weakened (Bhattacharya and Mitra, 1989; Satyasai and Viswanathan, 1999). The deteriorating linkages lead to the fall in the demand for agricultural products leading to the decline in share of agro-based industries as well we slow employment growth (Rangarajan, 1982; Bhattacharya and Rao, 1986; Chowdhury and Chowdhury, 1995). Sastry et al., (2003) found that between 1982 to 2000 , there was decline in forward production linkage between agriculture and industry but increase in backward production linkage. This resulted decline in agriculture's demand linkage to industry while the linkage increased from industry to agriculture.

The study made by Singh, 2007 and Gordon and Gupta, 2004 revealed that unlike the linkage between agriculture and industry was two-way interdependence, there was one-way linkage between agriculture and service sectors and it was particularly backward linkage. On the other hand, there were twoway linkages between industry and service sector and linkage level was bit higher compared to agriculture sector. Further, with both agriculture and industry sector there was stronger backward linkages of service sector compared to forward linkages.

Asep Suryahadi et al., (2006) estimated equations using both ordinary least squares (OLS) and instrumental variables (IV) model with the assumption of rural non-agricultural sectors as dependent variable and rural agricultural sectors as well as urban sector growth (GDP level) as independent variables with population growth, initial rural poverty rate, initial rural Gini ratio for inequality income distribution and other important variables as control variable found the agricultural demand linkages. The study found that the growth of agricultural sector strongly induces growth of non-agricultural sector in rural areas of Indonesia.

In twentieth century, the work inspired by Wassily Leontif i.e., input-output analysis is 
considered as one of the foremost contribution to the economy. Hugo Reis and Antonia Rua in 2006 studied about the linkages and leakages in an input-output analysis in Portugal Economy. They assessed sectoral interdependence and effects of trade for individual sector and also for economy as a whole. They concluded from the study that increase in interdependence coefficient is associated with decrease in coefficient of leakage nd vice versa. Likewise, based on decadal data, concentrating on importance of service sector leads to moderate increase in Portuguese sectoral interdependence.

\section{Social Accounting Matrix (SAM)}

The Social Accounting Matrix (SAM) which is said to originate from previously Leontief input-output model is a square matrix transaction occurring within an economy in a given period of time. The structure and interrelationships among the sectors and institutions of an economy will be presented in SAM. It is "the presentation of SNA (system of national accounts) accounts in a matrix which elaborates the linkages between a supply and use table and institutional sector accounts" (CEC et al., 1993). Entries along a row in the SAM indicate receipts or revenues, and entries down to the column indicate payments or expenditures. Generally the schematic structure of the SAM includes sectors like production, household, firms/industries, institutions, capital and Rest of World (ROW).

SAM provides information on demand and production for different sectors. Based on that, the production technologies across all sectors are calibrated to their present situation, including each sector's use of primary inputs, such as land, labor and capital, and intermediate inputs. To capture the existing difference at regional level, the agriculture was differentiated into small and large farm sectors and livestock as separate sector. Household is categorized as rural and urban sectors in which rural is further sub-divided as cultivator, agricultural laborer, self employed and non-agricultural labor, similarly urban as agriculture dependent, government employed, self employed and non-agricultural labourer. Then the firms representing different sectors other than agriculture and households were considered (Chinnadurai, 1996).

Workers in an economy can migrate between the sectors, although agricultural family laborers remain on their farms. Since the selfemployed agricultural labor force grows more slowly when compared to the rest of the labor force, the model sometimes accounts for the movement of rural laborers to the urban sectors or to the some other sectors where the value of the labor will be higher by finding employment opportunities through the labor market. Capital account moves freely within agricultural and non-agriculture sectors and capital is accumulated by domestic savings and foreign inflow. Based on the relative profitability, increased capital is allocated across the sectors. Incomes from employment mount up to different households. This detailed specification of production and factor markets in the model allows it to capture the changing scale and technology of production across sectors, thereby reflecting how changes in structure of growth influences its distribution of incomes (Samuel Benin et al., 2008).

Chinnadurai (1996) made distinction between 'activities' and 'factors' while constructing SAM. 'Activities' represents the producing sectors in input-output matrix. It is assumed to consist of producers who are behaviorally distinct in models. Similarly factor accounts indicate payment for factor of production (land, labor and capital) and distributing factor incomes to institutions. In the study regional level SAM was constructed to study the 
interdependence among the sectors. In the study it was concluded that cotton textile was leading sector followed by agriculture, food and garments. They all together contributed nearly 69.59 per cent of total income of 19 production sector considered in his study. After constructing SAM, he used linear programming framework to optimize economy's income. Each sector was considered as objective function in order to maximize its income and other sectors were taken as constraints, then the contribution of the other sectors towards maximizing income of objective function was noticed.

Ming- chang Lee and Li-Er Su, 2014 revealed that there are five major method revealed that there are five major method to balance the unbalanced SAM. They are 1) The RAS methods, 2) Cross-entropy (CE) method, 3) Method of Least squares, 4) Linear programming by minimizing with norm and 5) GAMS. They made a comparative study among the five models in order to conclude the most effective and accurate method in balancing SAM. As a result they concluded that more accurate one is $\mathrm{CE}$ method than other methods.

The SAM to be suitable for research purpose should have some most important characteristics like (Alarcon, Adamson et al., 1999).

Comprehensive: The circular flow of the economy as a whole should be reflected by SAM.

Consistent: As per Walrasian General Equilibrium rule, the market should be balanced.

Transparent: An objective view of structural economic and social relations of the economy considered for the study should be provided by SAM.

Flexible: The constructed SAM must be utilized for developing CGE models or in expanding these by including additional models which are relevant, like demographic data, social and environmental indicators or both.

\section{Outline of Social Accounting Matrix (SAM) Framework}

Row 1: In this study production activities indicate agricultural related activities in the farm. For producing goods and services, many inputs are required through many sources as mentioned in column 1 . The inputs are purchased from firms and enterprises (row 3), some given by the government for lower subsidy (row 4) and some from outside the region/country (row 6). These are purchased through capital account (row 5), by getting loan from the bank and other private agencies (row 4), through income they earn (row 2). Some of the inputs are retained for cultivation in the next season in order to save the purchasing expense (row 1) or are purchased within the regions and the employment of factor of production (row 2). Sometimes part of revenue is paid as sales tax to the government (row 4), part is retained by the farms for re-investment (row 5) and remaining profits are allocated to the households owning the business as payment for their own factor use (row 2). Column 1 indicates the way in which earned profits had been spent.

Goods and services which are produced through production activities are supplied through many means as summarized in row 1, i.e., the way through which the income is earned or saved. The earned income will be saved when some intermediate inputs are retained for next production season (column 1), when household purchases some commodities for own consumption (column 2), The firms and enterprises purchases output of the farm to use as intermediate inputs (column 3), when government purchases some commodities directly from the farmers with 
the intention to provide the same at very cost through subsidy, co-operative societies or public distribution system (column 4). Sometimes the commodities (column 1) are directly exported to other part of the country (column 5) or indirectly through government (column 4) (Table 1).

In total, gross value of output (row1, column 7) must be equal to the total cost of production (row 7, column1).

Row 2: Household earns income through the sources shown in row2. By earning profits from production activities and firms and enterprises, by transfers among each other through column 1 and column 3 , by inter household transfers (column 2), by self employment in production activities (column 1) and firms and enterprises (column 3) and while earning wages from the same. Also earns profit through salaries from government or private employment and from transfer payments like pension. Earns interest from bank (column 4) and as remittances from abroad (column 6). Generates income by investment made through capital account (column 5), when household owns farms (column 1) and firms and enterprises (column 3), some income may be earned through government procurement (column 4) and export (column 6) and transfer of goods and services (from column 1 to column 3 and vice versa).

The earned income by the household will be spent as shown in column 2. For consumption expenditure (row 1 and row 3), for inter household transfer (row 2), by paying income tax to the government (row 4), by investment on row 1 and row3 through row 5. By allocating factor income to row 1 and row3, by savings (row 5) for investment, by interest payment on consumer loans (row 4), by importing from other countries (row 6).
In general, total current receipts from household (row2, column 7) must be equal to total current outlays of household (row 7, column 2).

Row 3: firms and enterprise earns profits when output are demanded as inputs in production activities (column 1), when output of one firm and enterprises (column 3) are used as input in other one, when owner of the household itself is a labor, the wages will be saved (column 2), by allocating factor income to the household (column 2), when firms and enterprise purchases raw materials from column 1 and converts the same into the processed one (column 3) and is sold to household, government and outside the region (column 2, column 4 and column 6), when government (column 4) procures some commodities from column 3 and supply the same at lower cost for income population through public distribution system, cooperative societies and farmers, by earning some interest through capital account (column $5)$, through direct export to other parts of the country (column 6), when some inputs like machineries are leased to the farming group (column 1).

Similarly column 3 represents the way in which earned profits had been spent. By purchasing some intermediate inputs from production activities (row 1) and firms and enterprises (row 3) for further production process, by paying corporate tax, by distributing profit to the household (row 2), through savings made in capital account (row 5) for further investment, by providing wages and income to the people employed (row 2), expenses made while importing some commodities from other countries (row 6), while repaying loan (row 4).

In sum, total current receipts from firm (row3, column7) must be equal to total current outlays of firm (row7, column3). 
Row 4: Government receives tax from farms (column 1), income tax from household (column 2), corporate tax from firms and enterprises (column 3), tax is also collected from government operated business like civil supply shops (column 4) and receives fiscal transfer from district and state government (column 6), bank also receives repayment of loan from three sectors like column 1, 2 and 3. Apart from these, government receives income from sales of commodities e.g: food and kerosene in public distribution system, cooperative societies, farms and etc., (column 4), banks earns interests (column 5), government also earns income by exporting some commodities (column 6) to other countries.

Government outlays the income while procurement of commodities from local suppliers (row 1), firms and enterprises (row 3) and through import (row 6), consist of transfer to household (row 2), paying tax to government operated business (row 4), factor payments like salaries and pensions (row 2). Apart from all, government saves any surplus fiscal funds for further investment activities (row 5). Some of the funds will be allocated in farms and dependant household at the time of disaster (row 1 and row 2).

As a whole, total current outlay of government (row 7, column4) must be equal to total current receipts from government (column 7 , row 4).

Row 5: Capital account includes both public and private investment. Sources of funding are retained profits, savings made by farms, household, firms and public and private agencies (column 1,2,3 and 4), net capital inflow from other parts of the country (column 6), by earning payment from household (column 2), earning interest from government (column 5). Column 5 shows the way in which capital funds are spent. By buying capital commodities within the region (row 1 and 3 ) and outside the region (row 6), by hiring factors like labor for investment activities (row 2) and through investment within (row 1 and 3) and outside the region (row 6). In summation, total current receipts from capital account (row5, column7) must be equal to total capital payment made (row7, column 5).

Row 6: Shows import made by the region for which the commodity is not locally available. Includes import made for production activities and local trading (row 1), by firms and enterprises (row 3), by households (row 2), by public and private institutions (row 4). Region's earnings are shown in row 6. It includes export of commodity (column 1, column 3 and column 4), household remittances (column 2) and transfer to government from district or state sources (column 4). There may be capital outflow and inflow from the region (row6, column6). In general, total leakages or payment to abroad (row 6, column 7) must be equal to total injections or receipts from abroad (row7, column6).

\section{Computable General Equilibrium (CGE)}

Interdependencies among market economy will be captured be General Equilibrium Analysis in which there will be inter relation between prices and production of all goods and proves that different agents in an economy cannot operate in isolation. It aims in estimating the magnitude of changes between original and the new equilibrium. Computable General Equilibrium (CGE) model provides a comprehensive framework to capture the various repercussions of policy interventions and measure their impact on agriculture. The CGE and micro simulation model used to examine the impact of current growth in an economy for the improvement of the weaker section of the economy. The CGE model captures the initial cropping patterns of each farm types. Farmers sometimes (represented 
by the various farm types) tries to maximize their income by responding to changes in production technology, commodity demand and prices by reallocating their land across different crops. These representative farmers reallocate their labor and capital between farm and non-farm activities, including livestock, fishing and other allied sectors, wage employment on other people's farms, and migration to non-agriculture in more urbanized sectors.

By capturing farm level production information across sub-national regions, the CGE model effectively integrates data on different sectors and activities into an economy-wide model that can assess growth effects at the national level, while taking into account the micro-level decision-making typically associated with more detailed farm models. The CGE model is therefore an ideal tool for capturing the growth linkages and income- and price-effects resulting from accelerating growth in different agricultural sectors. Finally, the CGE model endogenously estimates the impact of alternative growth paths on the incomes of various household groups. These household groups follow the farm typology by including farm and non-farm households, and being disaggregated across rural areas, the major city and other smaller urban centers (Samuel Benin et al., 2008).

The study made by Samuel Benin et al., (2008) analyzed the agricultural growth and investment options which can support the development of comprehensive rural development component which includes the achievement of six per cent agricultural growth as per Comprehensive African Agriculture Development Programme (CAADP) target. Their CGE modeling result finally concluded that by additional growth of number of crops and sub-sectors (like fisheries and livestock), it is possible for Uganda to reach CAADP target.
An important factor determining the contribution of agriculture to overall economic growth is its linkages with the rest of the economy. Agriculture's proponents argue that agriculture has strong growth-linkages. The model captures production linkages by explicitly defining a set of nested constant elasticity of substitution (CES) production functions, and allowing producers to generate demand for both factors and intermediates. The CGE model also captures forward and backward production linkages between sectors. Import competition and export opportunities are modeled by allowing producers and consumers to shift between domestic and foreign markets depending on changes in the relative prices of imports, exports and domestic goods. More specifically, the decision of producers to supply domestic or foreign markets is governed by a constant elasticity of transformation (CET) function, while substitution possibilities exist between imports and domestically supplied goods under a CES Armington specification. In this way, the model captures how import competition and the changing export opportunities of agriculture and industry can strengthen or weaken the linkages between growths and poverty.

Two kinds of parameters are essentially to be estimated for CGE models

1. The major economic share parameters like costs of intermediate input, share of consumer expenditure, saving rate at average level, shares of import and export, shares of government expenditures and average tax rates. These parameters are estimated by construction of SAM in a base year.

2. The curvature of various structural functions which are described by elasticity parameters (like utility functions, production function, export supply function, import demand function etc.). 
In general, the CGE model incorporates distributional change by (i) disaggregating growth across sectors; (ii) capturing incomeeffects through factor markets and priceeffects through commodity markets; and (iii) translating these two effects onto each household in the survey according to its unique factor endowment and income and expenditure patterns.

Table.1
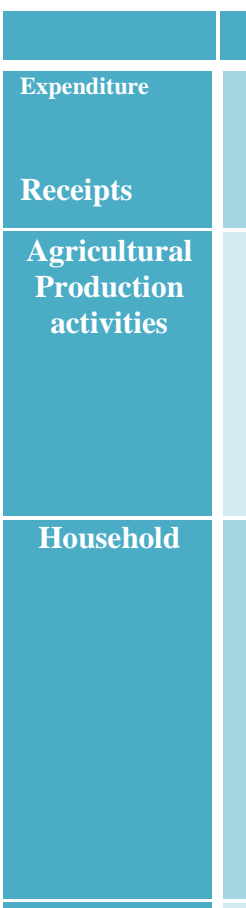

Firms \&

Enterprises
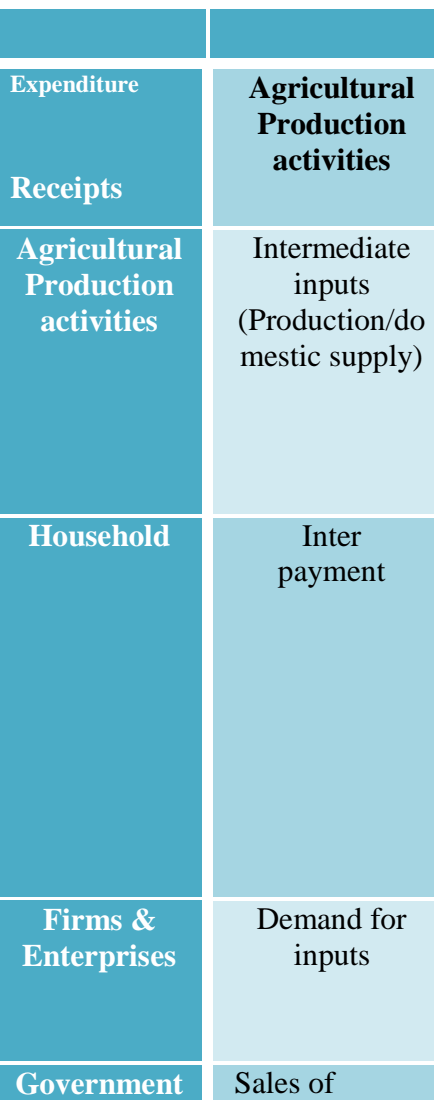

\begin{tabular}{|c|}
\hline Institut \\
\hline Household \\
\hline \\
\hline $\begin{array}{c}\text { Consumption } \\
\text { expenditure }\end{array}$ \\
\hline
\end{tabular}

nstitutio
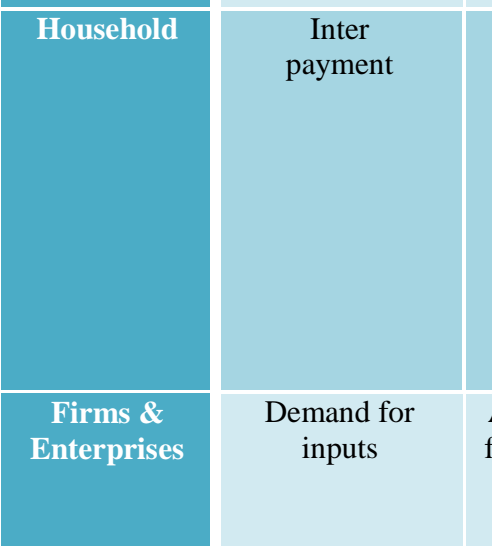

\section{Demand for inputs}

\section{Allocation of} factor income

Inter
household
transfers

\section{Distribution of} profits

\section{(}
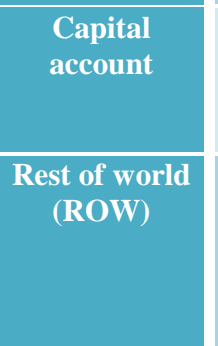

\begin{tabular}{|c|}
\hline Retained profits \\
\hline $\begin{array}{c}\text { Import of raw } \\
\text { materials }\end{array}$ \\
\hline $\begin{array}{c}\text { Total cost of } \\
\text { production }\end{array}$ \\
\hline
\end{tabular}

Sales of
commodity/
bank payment

\begin{tabular}{l|l} 
Income tax & Corporate tax \\
\hline
\end{tabular}

Current
transfer/
payment
transfer
Government
supplies

Interest
earnings by
household

net curren transfer from ROW (All ins. Current accnt)

\begin{tabular}{c|c|c|}
$\begin{array}{c}\text { Household } \\
\text { savings }\end{array}$ & $\begin{array}{c}\text { Enterprise } \\
\text { savings }\end{array}$ & $\begin{array}{c}\text { Public } \\
\text { savings }\end{array}$ \\
\hline
\end{tabular}

Revenue allocation

Import by
households
Total current
outlays of

\begin{tabular}{|c|}
\hline Import by \\
\hline enterprise \\
\hline $\begin{array}{c}\text { Total current } \\
\text { outlays of firm }\end{array}$ \\
\hline
\end{tabular}

Import by
government

Total
current
outlays of
Gvt

Interest
earnings by
government

$\begin{gathered}\text { Transfers } \\ \text { from } \\ \text { government }\end{gathered}$
Net capital
inflow

\section{Total current} receipts from Gvt

Total current receipts from capital account

\begin{tabular}{|c|c|}
\hline $\begin{array}{c}\text { Import of } \\
\text { capital } \\
\text { goods }\end{array}$ & $\begin{array}{c}\text { Investment } \\
\text { goods }\end{array}$ \\
& \\
\hline
\end{tabular}
Total Leakages/ payment to abroad
Total capital payment of $\mathrm{HH}$

Total household

injections/

receipts

from

abroad 


\section{Simulation and policy analysis}

The analysis of multipliers by means of SAMs makes it possible to generate simulations that provide the criteria for identifying key sectors of the economy. They identify not only those with greater production linkages but also those that generate more value added and have better effects on the distribution of income between rural and urban households.

In an existing market, socio - economic systems or other unit of inquiry, simulation is an attempt to reproduce on small scale actual or essential features. It is considered as one of the powerful and most needed tool for policy makers in examining and investigating the impact of various policy measures on the economy.

The optimizing behavior of the simulation attempts in identifying the decisions which helps in maximizing profits, security or efficiency or in minimizing cost. Likewise in structural and predictive models, structural models are used in emphasizing causal relationship among the most important variables of the economic system while predictive model helps in forecasting the future outcomes. Once the structure of the model is specified it helps in determining on what data and statistical analysis will be needed to estimate parameter values and test the validity of the model (Rafael Trejos et al., 2004).

Since the simulation model is used widely, micro simulation method had been developed recently.

Micro simulation is used as an essence in establishing a link between the behavior observed in various micro level data and macro aggregates to provide estimates in the way from which various aggregates changes in response to innovation of policy.

\section{Necessity for policy models}

To get effective policy analysis, the model should have some desirable features (Shantayanan Devarajan and Sherman Robinson, 2002).

Relevance in policy: There should be some relevance between values of policy variables with economic outcomes to policy makers of useful in policy debates.

Transparency: The linkage between policy variables and outcomes should be traceable easily and explainable.

Timeliness: Based on relevancy in data the policy models should be framed and it must be implemented with current data if they are to be used in recent policy debate.

Validation and estimation: There should be validation in estimation of the model parameters and behavior of the model in order to domain the application of the model. Therefore the determination of the model should be able to achieve the accuracy of the result and the domain of potential policy choices under policy debate consideration.

Diversity of approaches: By analyzing the economy using variety of models at different levels of aggregation, the validating results from the policy models is greatly strengthened. This diversity is used to test the robustness of the results and the importance of assumptions made by various approaches.

\section{References}

Adamson, M., Montiel, N., Alarcón, J., Vargas, H., Solano, A., Sandoval, F, 1999. Matrices de Contabilidad social: nota metodológica y una propuesta para Costa Rica. San José, Costa

Rica, IICE-Universidad de Costa Rica.

Asep Suryahadi et al., (2006), Agricultural Demand Linkages and Growth Multiplier in Rural Indonesia, SMERU Working Paper.

Bathla S (2003). Inter-sectoral Growth Linkages 
in India: Implications for Policy and Liberalized Reforms. Accessed from www.ccssr.org.cn/ new/uploadfile/2008680718733.pdf.

Bhattacharya BB, Mitra A (1989). IndustryAgriculture Growth Rates: Widening Disparity. Economic and Political Weekly, 24(34): 1963-70.

Bhattacharya BB, Rao CHH (1986). AgricultureIndustry Interrelations: Issues of Relative Prices and Growth in the Context of Public Investment. Theme 18, Eighth World Economic Congress of the International Economic Association, New Delhi.

CEC (Commission of the European Communities), International Monetary Fund, Organisation for Economic Co-operation and Development, United Nations, and World Bank. 1993. System of National Accounts 1993. Brussels/Luxembourg., New York., Paris., Washington, DC.

Chinnadurai, M. (1996). A Social Accounting Based Regional Model for Studying the Impact of Policy Simulations- An Application to Western Tamil Nadu, Unpublished Ph.D., Dissertation, Department of Agricultural Economics, Tamil Nadu Agricultural University.

Chowdhury K, Chowdhury MB (1995). Sectoral Linkages and Economic Growth in Asia: Evidence from Granger Causality Test. Indian Econ. J., 42: 59-75.

Dilip Saikia (2012). Agriculture and Industry: Analysing Linkages for Pre- and Post-reform Periods in India, Research Gate. See discussions, stats, and author profiles for this publication at: https://www.researchgate.net/ publication/263723424

Gordon J, Gupta P (2004). Understanding India's Services Revolution. IMF Working Paper WP/04/171, IMF.

Hirschman AO (1958). A Strategy for Economic Development. Yale University Press, New
Haven.

Hugo Reis, Antonio Rua (2006), An Input-Output Analysis: Linkages Vs Leakages, Working Paper.

Ming-Chung Lee, Li-Er Su (2014). Social Accounting Matrix Balanced Based on Mathematical Optimization Method and General Algebraic Modelling System. British Journal of Economics, Management and Trade, 4(8): 1174-1190

Nayyar D (1978). Industrial Development in India: Some Reflections on Growth and Stagnation. Econ. Polit. Wkly, 13(31/33): 1265-78

Patnaik P (1972). Disproportionality Crisis and Cyclical Growth: A Theoretical Note. Econ. Polit. Wkly, 7(5/7): 329-36

Rafael et al., (2004). More than Food on Table Agriculture's True Contribution to the Economy. IFPRI.

Rangarajan C (1982). Agricultural Growth and Industrial Performance in India. Research Report 33, International Food Policy Research Institute.

Samuel Benin et al., (2008). Agriculture Growth and Investment Options for Poverty Reduction in Uganda. International Food policy Research Institute

Sastry DVS, Singh B, Bhattacharya K, Unnikrishnan NK (2003). Sectoral Linkages and Growth Prospects: Reflections on the Indian. Econ. Polit. Wkly, 38(24): 2390-97.

Satyasai KJS, Viswanathan KU (1999). Dynamics of Agriculture-Industry Linkages. Indian J, Agric, Econ., 54(3): 394-401.

Singh N (2007). Services-led Industrialization in India: Assessment and lessons. In Industrial Development for the 21st Century: Sustainable Development Perspectives, Department of Economic and Social Affairs, United Nations, New York.

\section{How to cite this article:}

Sangeetha, P. and Chinnadurai, M. 2018. Intersectoral Linkage by Computable General Equilibrium Approach. Int.J.Curr.Microbiol.App.Sci. 7(12): 767-776. doi: https://doi.org/10.20546/ijcmas.2018.712.095 